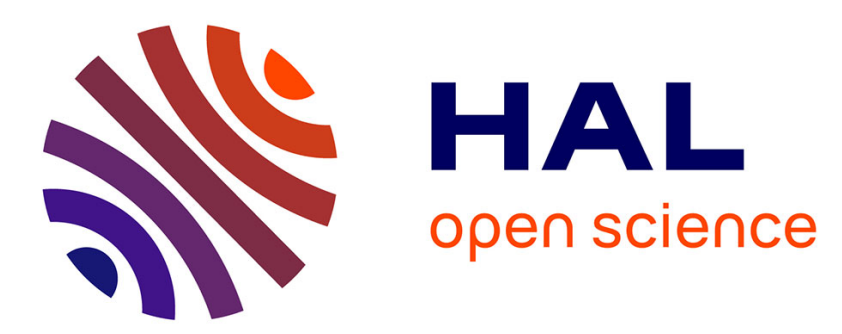

\title{
Biomass hydrolysis inhibition at high hydrogen partial pressure in solid-state anaerobic digestion
}

\author{
Elisabeth Cazier, Eric Trably, Jean-Philippe Steyer, Renaud Escudié
}

\section{To cite this version:}

Elisabeth Cazier, Eric Trably, Jean-Philippe Steyer, Renaud Escudié. Biomass hydrolysis inhibition at high hydrogen partial pressure in solid-state anaerobic digestion. Bioresource Technology, 2015, 190, pp.106-113. 10.1016/j.biortech.2015.04.055 . hal-01149953v2

\section{HAL Id: hal-01149953 \\ https://hal.science/hal-01149953v2}

Submitted on 12 Oct 2015

HAL is a multi-disciplinary open access archive for the deposit and dissemination of scientific research documents, whether they are published or not. The documents may come from teaching and research institutions in France or abroad, or from public or private research centers.
L'archive ouverte pluridisciplinaire HAL, est destinée au dépôt et à la diffusion de documents scientifiques de niveau recherche, publiés ou non, émanant des établissements d'enseignement et de recherche français ou étrangers, des laboratoires publics ou privés. 


\section{Accepted Manuscript}

Biomass hydrolysis inhibition at high hydrogen partial pressure in solid-state anaerobic digestion

E.A. Cazier, E. Trably, J.P. Steyer, R. Escudie

PII:

S0960-8524(15)00562-3

DOI: http://dx.doi.org/10.1016/j.biortech.2015.04.055

Reference: BITE 14896

To appear in:

Bioresource Technology

Received Date: $\quad 18$ February 2015

Revised Date: $\quad 15$ April 2015

Accepted Date: $\quad 16$ April 2015

Please cite this article as: Cazier, E.A., Trably, E., Steyer, J.P., Escudie, R., Biomass hydrolysis inhibition at high hydrogen partial pressure in solid-state anaerobic digestion, Bioresource Technology (2015), doi: http://dx.doi.org/ 10.1016/j.biortech.2015.04.055

This is a PDF file of an unedited manuscript that has been accepted for publication. As a service to our customers we are providing this early version of the manuscript. The manuscript will undergo copyediting, typesetting, and review of the resulting proof before it is published in its final form. Please note that during the production process errors may be discovered which could affect the content, and all legal disclaimers that apply to the journal pertain. 
Biomass hydrolysis inhibition at high hydrogen partial pressure in solid-state anaerobic digestion

E.A. CAZIER ${ }^{\mathrm{a}}$, E. TRABLY ${ }^{\mathrm{*}}$, J.P. STEYER ${ }^{\mathrm{a}}, \mathrm{R}^{\mathrm{E}}$ ESCUDIE $^{\mathrm{a}}$

a INRA, UR0050, Laboratoire de Biotechnologie de l'Environnement, Avenue des Etangs, 11100 Narbonne, France

* Corresponding author: eric.trably@supagro.inra.fr; Phone: (+33) (0) 468425 172; Fax: (+33) (0) 468425160 


\begin{abstract}
In solid-state anaerobic digestion, so-called ss-AD, biogas production is inhibited at high total solids contents. Such inhibition is likely caused by a slow diffusion of dissolved reaction intermediates that locally accumulate. In this study, we investigated the effect of $\mathrm{H}_{2}$ and $\mathrm{CO}_{2}$ partial pressure on ss-AD. Partial pressure of $\mathrm{H}_{2}$ and/or $\mathrm{CO}_{2}$ was artificially fixed, from 0 to 1 557 mbars for $\mathrm{H}_{2}$ and from 0 to 427 mbars for $\mathrm{CO}_{2}$. High partial pressure of $\mathrm{H}_{2}$ showed a significant effect on methanogenesis, while $\mathrm{CO}_{2}$ had no impact. At high $\mathrm{P}_{\mathrm{H} 2}$, the overall substrate degradation decreased with no accumulation of metabolites from acidogenic bacteria, indicating that the hydrolytic activity was specifically impacted. Interestingly, such inhibition did not occur when $\mathrm{CO}_{2}$ was added with $\mathrm{H}_{2}$. This result suggests that $\mathrm{CO}_{2}$ gas transfer is probably a key factor in ss-AD from biomass.
\end{abstract}

\title{
Keywords
}

Dry anaerobic digestion; gas transfer; hydrogen; hydrolysis; lignocellulosic residues.

\section{Introduction}

Over the past decade, solid-state anaerobic digestion (ss-AD) also called dry anaerobic digestion or high-solids AD has gained a wide interest in Europe. Agricultural waste and organic fraction of municipal waste had been particularly used as substrates (Baere et al., 2010). In ss-AD, organic matter contained in the waste is biologically converted by anaerobic bacteria into a biogas composed of $\mathrm{CH}_{4}(50-70 \%)$ and $\mathrm{CO}_{2}$ (30-50\%). Remaining organic matter called digestate can be further reused on land as fertilizer with several sanitary and environmental restrictions. The biogas produced by AD can be converted into electricity and heat by cogeneration or, after purification, can be used as biofuel $\left(95 \%\right.$ of $\left.\mathrm{CH}_{4}\right)$ or directly injected in natural gas pipelines (Weiland, 2010).

Anaerobic digestion is composed of four microbial steps: first, organic matter (proteins, lipids and polysaccharides) is hydrolyzed into soluble molecules by extracellular enzymes excreted by hydrolytic microorganisms (Montero et al., 2008). Hydrolysis is mostly the limiting step of AD when solid organic matter is used as substrate (Pavlostathis and Giraldo-Gomez, 1991). The second step corresponds to acidogenesis: amino-acids, saccharides and fatty acids are transformed into volatile fatty acids (VFAs) such acetate, butyrate, propionate, or into others organics acids, such as lactate, or in alcohols, i.e. ethanol, butanol, in presence of fermentative 
microorganisms such as Clostridium sp. (Fritsch et al., 2008). The third step is called acetogenesis where all types of VFAs are transformed into acetate, $\mathrm{CO}_{2}$ and $\mathrm{H}_{2}$ by two types of microorganisms: (1) syntrophic acetogens, e.g. Syntrophobacter wolinii or Syntrophomonas wolfei, also called Obligate Hydrogen Producing Bacteria (OHPB), are converting VFAs, alcohols and fatty acids to $\mathrm{H}_{2}, \mathrm{CO}_{2}$ and acetate (Amani et al., 2010). These microorganisms are synthrophs of methanogens since all acetogenic reactions are thermodynamically not favorable and end-products accumulation can inhibit their own production, in particular hydrogen (2) non synthrophic homoacetogens, e.g. Clostridium aceticum, are using $\mathrm{H}_{2}$ and $\mathrm{CO}_{2}$ to produce acetate (Amani et al., 2010). In this case, the reaction is thermodynamically favorable and does not require the presence of methanogenic Archaea. Acidogenesis is also impacted by $\mathrm{H}_{2}$ and $\mathrm{CO}_{2}$ in wet $\mathrm{AD}$ and more specifically the production of propionate, butyrate and caproate (Arslan et al., 2012). Acetate and butyrate are concomitantly produced with $\mathrm{H} 2$ and the consumption of these VFAs may be inhibited by high $\mathrm{P}_{\mathrm{H} 2}$ ( Ahring and Westermann, 1988; Ding et al., 2010; Hallenbeck, 2005). The last step corresponds to methanogenesis. Acetate, $\mathrm{H}_{2}$ and $\mathrm{CO}_{2}$ are transformed into $\mathrm{CH}_{4}$ by two types of microorganisms: (1) acetotrophic methanogens using acetate as substrate and producing $70 \%$ of $\mathrm{CH}_{4}$ in $\mathrm{AD}$ (Pavlostathis and Giraldo-Gomez, 1991) such as Methanosaeta concilii or Methanosarcina acetivorans (Amani et al., 2010), (2) hydrogenotrophic methanogens using $\mathrm{CO}_{2}$ and $\mathrm{H}_{2}$ as substrates, such as Methanobacterium bryantii or Methanobrevibacter arboriphilus (Amani et al., 2010).

Two main types of technologies have been developed to convert the solid organic matter in anaerobic digestion : wet $\mathrm{AD}$ and solid-state $\mathrm{AD}$ (ss-AD), with a Total Solids (TS) content below or higher than $15 \%$, respectively (Baere et al., 2010). ss-AD presents several advantages such as reducing the water demand and lowering the costs related to water management, with a subsequent reduction of reactor size and less energy requirements for heating. These advantages contributed to a recent and large industrial development of ss-AD, with a rapid emergence of full-scale plants (Baere et al., 2010). Industrial digesters usually use agricultural, green or solid organic waste, under a TS content ranging from 15 to $30 \%$. Since many industrial installations have been empirically developed, recent research has been devoted to optimize ss-AD processes through a better understanding of their limitations (Abbassi-Guendouz et al., 2012; Motte et al., 2013).

The key parameter driving the microbial processes in ss-AD is low water content since microbial end-products can locally accumulate and inhibit methanogenesis (Abbassi- 
Guendouz et al., 2012). In such systems, water availability presents two distinct forms: (1) "free water" that can act as a solvent for salts and soluble compounds (Pommier and Chenu, 2007), (2) "bound water" that has more structural bonding (chemical and physical interactions) than liquid or free water and thus, is unable to act as a solvent. The form of water depends mainly on the structure and composition of the organic matter structure. Moreover, when the TS content increases, the quantity of free water decreases (García-Bernet et al., 2011) and the transport of soluble content within the substrate can become a limiting factor (Bollon et al., 2013). Microbial activity can be impacted by water availability and methane yields varies significantly between wet and ss-AD, according to the nature of the substrate. Brown et al. (2012) reported that $\mathrm{CH}_{4}$ yields of paper decreased from 19.2 L/kg TS to 8.7 $\mathrm{L} / \mathrm{kg}$ TS in wet and ss- $\mathrm{AD}$, respectively. In contrast, no $\mathrm{CH}_{4}$ yields variation was observed with wheat straw, i.e. $11.6 \mathrm{~L} / \mathrm{kg}$ TS (wet AD) and $12 \mathrm{~L} / \mathrm{kg}$ TS (ss-AD). Overall, by increasing the TS content, substrate degradation and consequently the biogas production are reduced (Abbassi-Guendouz et al., 2012; García-Bernet et al., 2011; Motte et al., 2013). As an illustration, a decrease of organic waste degradation by $17 \%$ was observed when changing the TS content from 20 to $30 \%$ (Fernández et al., 2008).

When the water content decreases, the rheological behavior of the substrate is also modified (García-Bernet et al., 2011). Therefore, the diffusion of metabolic compounds within the substrate at a macroscopic level is lowered (Bollon et al., 2013). The limitation of ss-AD might be explained by the slow diffusion of dissolved inhibitory products inside the organic matrix generating local accumulation at microbial scale (Martin, 2001; Staley et al., 2011). In a recent study, Abbassi-Guendouz et al. (2012) suggested that methanogenesis inhibition at high solids content was mainly caused by gas transfer limitation and more particularly by a local accumulation of gases $\left(\mathrm{H}_{2}\right.$ and $\left.\mathrm{CO}_{2}\right)$ leading to VFAs accumulation. $\mathrm{H}_{2}$ has a welldescribed inhibitory effect on wet $\mathrm{AD}$ but the exact effect of $\mathrm{H} 2$ on ss-AD remains unknown. The objective of this study was to investigate the effect of dissolved gases on ss-AD. The accumulation of $\mathrm{H}_{2}$ and $\mathrm{CO}_{2}$, as by-products of acidogenesis, was investigated in particular since local accumulation of these gases may impact the overall ss-AD process. Experiments were designed and carried out to evaluate the effect of the partial pressure of $\mathrm{H}_{2}$ alone or mixed with $\mathrm{CO}_{2}$ on the overall reaction of ss-AD. 


\section{Materials and methods}

\subsection{Substrate preparation}

Wheat straw (Triticum aestivum) was used as model substrate representing lignocellulosic agricultural waste for its well-known composition in hemicelluloses, cellulose and lignin (Vassilev et al., 2012). Particles were fractionated in a cutting miller through a $1 \mathrm{~mm}$ grid, and further sieved between grids of $1 \mathrm{~mm}$ and $400 \mu \mathrm{m}$. Wheat straw particles had a TS content of $95 \%$.

\subsection{Operating conditions of the batch tests}

Granular sludge originated from an industrial UASB reactor treating sugar factory effluents was used to inoculate the batch reactors. The sludge was mixed during $24 \mathrm{~h}$ at $35^{\circ} \mathrm{C}$ to break the granules, and then centrifuged at $7841 \mathrm{~g}\left(20 \mathrm{~min}, 4^{\circ} \mathrm{C}\right)$ to obtain a microbial anaerobic inoculum with a TS content ranging between 10 to $13 \%$. Final $\mathrm{pH}$ of the inoculum was 7.8.

A substrate/inoculum biomass (S/X) ratio of 3 (in volatile solids basis) was used as suggested elsewhere (Liew et al., 2012). The initial TS content of the flask was fixed at $25 \%$ where no inhibition of AD was reported (Abbassi-Guendouz et al., 2012; Motte et al., 2013). Wheat straw and inoculum were added in a S/X ratio of 3 and TS content was adjusted with the buffer solution after addition of trace elements. At this TS content, A solution of trace elements $\left(\mathrm{FeCl}_{2} 2 \mathrm{~g} / \mathrm{L}, \mathrm{CoCl}_{2} 0.5 \mathrm{~g} / \mathrm{L}, \mathrm{MnCl}_{2} 0.1 \mathrm{~g} / \mathrm{L}, \mathrm{NiCl}_{2} 0.1 \mathrm{~g} / \mathrm{L}, \mathrm{ZnCl}_{2} 0.05 \mathrm{~g} / \mathrm{L}, \mathrm{H}_{3} \mathrm{BO}_{3}\right.$ $0.05 \mathrm{~g} / \mathrm{L}, \mathrm{Na}_{2} \mathrm{SeO}_{3} 0.05 \mathrm{~g} / \mathrm{L}, \mathrm{CuCl}_{2} 0.04 \mathrm{~g} / \mathrm{L}, \mathrm{Na}_{2} \mathrm{MoO}_{4} 0.01 \mathrm{~g} / \mathrm{L}$ ) was added with a volume of $0.2 \mathrm{~mL}$ by flask. A buffer solution of sodium bicarbonate $\left(0.0026 \mathrm{~g} \mathrm{NaHCO}_{3} / \mathrm{g}\right.$ substrate $)$ was added at the beginning to keep the $\mathrm{pH}$ around 7-8.

First, the medium (wheat straw, trace elements, buffer and inoculum) was introduced into a 3 $\mathrm{L}$ reactor operated during 10 days at $35^{\circ} \mathrm{C}$. This reactor was flushed with $\mathrm{N}_{2}$ to avoid the presence of $\mathrm{O}_{2}$. This pre-culture was performed to reach an active phase of methanogenesis and homogenize the substrate. Then, $20 \mathrm{~g}$ of the pre-culture was distributed in a thin layer $(<1$ $\mathrm{cm}$ ) at the bottom of a $600 \mathrm{~mL}$ flask. Such thin layer was used to minimize the influence of the gas diffusion within the medium. The flasks were flushed with $\mathrm{N}_{2}$ before the addition of other gases $\left(\mathrm{H}_{2}\right.$ alone or mixed with $\left.\mathrm{CO}_{2}\right)$. Whatever the gas added, the initial pressure was around 1.5 bars. The flasks were then incubated during 13 days at $35^{\circ} \mathrm{C}$ to evaluate the effect of the partial pressure of $\mathrm{H} 2$ and/or $\mathrm{CO} 2$ on the initial degradation of wheat straw in ss-AD. 
Experiments were conducted in five separate runs, with three to four replicates for each condition. An experimental design plan was performed in order to investigate the partial pressure of $\mathrm{H}_{2}\left(\mathrm{P}_{\mathrm{H} 2}\right)$ alone or mixed with $\mathrm{CO}_{2}\left(\mathrm{P}_{\mathrm{CO} 2}\right)$ (Table 1). When $\mathrm{H}_{2}$ was added alone, initial $\mathrm{P}_{\mathrm{H} 2}$ ranged from 0 to 1557 mbars. $\mathrm{CO}_{2}$ and $\mathrm{H}_{2}$ were also added simultaneously in a mixture corresponding to partial pressures of $\mathrm{H}_{2}$ and $\mathrm{CO}_{2}$ ranging from 0 to 1060 mbars and 0 to 427 mbars, respectively (Table 1). For each run, a control (only $\mathrm{N}_{2}$ in headspace) was carried out.

\subsection{Analytical methods}

Gas pressure and composition were measured periodically with an automated multiplexed micro-gas chromatograph ( $\mu$ GC R3000, SRA instrument) using 12 to 20 flasks at once. It was composed of an injector and two capillary columns heated at $90^{\circ} \mathrm{C}$ and $80^{\circ} \mathrm{C}$, respectively. One column corresponded to a MolSieve $5 \AA$ (with a length of $10 \mathrm{~m}$ and a diameter of 0.32 $\mathrm{mm}$ ) for analyzing $\mathrm{CO}_{2}$ with argon as carrier gas, at a pressure of $30 \mathrm{psi}$. The second column corresponded to a PLOT Q with a length of $8 \mathrm{~m}$ and a diameter of $0.32 \mathrm{~mm}$, and was used for analysis of the $\mathrm{O}_{2}, \mathrm{H}_{2}, \mathrm{~N}_{2}$ and $\mathrm{CH}_{4}$ with helium as carrier gas at a pressure of 20 psi. The detection was ensured by a thermal conductivity detector.

At the end of the experiment, $5 \mathrm{~g}$ of the medium were diluted in $20 \mathrm{~g}$ of deionized water, mixed during 30 minutes, and centrifuged at $39121 \mathrm{~g}$ during $20 \mathrm{~min}$ at $4^{\circ} \mathrm{C}$. The supernatant was then filtrated at $0.2 \mu \mathrm{m}$ with a nylon membrane, and was then used to measure VFAs, others microbial metabolites (formate, succinate, lactate, ethanol) and residual soluble sugars.

Volatile fatty acids (VFAs) were measured at start and at the end of each experiment. VFA concentrations were determined with a gas chromatograph Perkin Clarus 580 with an Elite-FFAP crossbond ${ }^{\circledR}$ carbowax ${ }^{\circledR} 15 \mathrm{~m}$ column connected to a flame ionization detector at $280^{\circ} \mathrm{C}$ and $\mathrm{N}_{2}$ at $6 \mathrm{~mL} \cdot \mathrm{min}^{-1}$ as carrier gas, as described elsewhere (Motte et al., 2013).

Others metabolites and soluble sugars were measured at start and at the end of each experiment. These compounds were quantified using high performance liquid chromatograph. This chromatograph was composed of an automatic sampler (Water 717), a pre-column to filter residues (Micro guard cation H refill cartridge, Bio-rad) and a Aminex HPX-87H column (300 mm on 7,8 mm, Bio-rad). The carrier liquid was sulfuric acid at $0.005 \mathrm{M}$ at 0.4 ml.min ${ }^{-1}$, as described elsewhere (Motte et al., 2013). 
The quantity of microorganisms (Bacteria and Archaea) was quantified using quantitative PCR (Polymerase Chain Reaction ) according to the protocol of Braun et al. (2011) and Bru et al. (2012). The community structures of Bacteria and Archaea were obtained using Capillary Electrophoresis Single Strand Conformation Polymorphism (CE-SSCP) using the protocol described by Wéry et al., (2008). The microbial community composition (Archaea and Bacteria) was evaluated by sequencing after purification of the PCR products, using the Illumina MiSeq System with 2x300 bp paired-end chemistry at the GenoToul sequencing center (www.genotoul.fr). An average of 81707 high quality sequences per sample for Archaea and 453382 high quality sequences per sample for Bacteria were retained after assembly, demultiplexing and cleaning steps in Mothur version 1.33.2 (Schloss et al., 2009). SILVA release 102 was used for alignment and as taxonomic outline.

\subsection{Data analysis}

Statistical analyses of the data obtained were performed using R software (version 2.15.2) with the package Rcmdr (version 1.8-4). Non-significant P-values were fixed $>0.05$ and significant $\mathrm{P}$-values were estimated when $<0.05 ;<0.01$ and $<0.001$.

Total substrate degradation was assessed with Chemical Oxygen Demand (COD) mass balance between the start and the end of the experiment. To avoid a high experimental error when determining the COD value from solids, wheat straw COD was not considered and all calculations were expressed according to the initial TS content. Total substrate degradation was estimated theoretically according to the end-products accumulation in the gas and liquid phases, as follows:

Total Substrate Degradation (Final State-Initial State)=

$\frac{A_{\mathrm{H}_{2}, \mathrm{f}}+\mathrm{A}_{\mathrm{CH}_{4}, \mathrm{f}}+\mathrm{A}_{\mathrm{met}, \mathrm{f}}+\mathrm{A}_{\mathrm{GC}}}{\mathrm{g} \mathrm{TS}}-\frac{\mathrm{A}_{\mathrm{H}_{2}, \mathrm{i}}+\mathrm{A}_{\mathrm{met}, \mathrm{i}}}{\mathrm{g} \mathrm{TS}}$ (Equation 1)

where, $\mathrm{A}_{\mathrm{H}_{2}, \mathrm{f}}$ is the final amount of $\mathrm{H}_{2}$ remaining in headspace, $\mathrm{A}_{\mathrm{CH}_{4}, \mathrm{f}}$ the final amount of $\mathrm{CH}_{4}$ accumulated in headspace, $\mathrm{A}_{\text {met,f } \mathrm{f}}$ the final amount of metabolites, $\mathrm{A}_{\mathrm{GC}}$ the total amount of gas $\left(\mathrm{H}_{2}\right.$ and $\left.\mathrm{CH}_{4}\right)$ sampled for analyses, $\mathrm{A}_{\mathrm{H}_{2}, \mathrm{i}}$ the amount of $\mathrm{H}_{2}$ initially added and $\mathrm{A}_{\text {met,i }}$ the initial amount of metabolites in the medium. 


\section{Results and discussion}

\subsection{Impact of high $P_{\text {H2 }}$ on methanogenesis}

Figure 1-a shows the cumulative $\mathrm{CH}_{4}$ production at the end of the experiment (i.e.13 days) according to the initial $\mathrm{H}_{2}$ partial pressure. In this figure, results from four different runs (Runs 1-4) inoculated with distinct pre-cultures are presented. Since the pre-cultures were not exactly from the same origin, cumulated $\mathrm{CH}_{4}$ production in the control samples $\left(\mathrm{P}_{\mathrm{H} 2}=0\right)$ showed a high variability. This was likely due to a slightly longer lag phase for $\mathrm{CH} 4$ production that was observed in the controls, although the pre-culture was active in all runs (see Supplementary material). A difference of few days ion the initial lag phase could have resulted in variability of cumulated $\mathrm{CH}_{4}$ after 13 days of experiment. Adding $\mathrm{H} 2$ in headspace at start of the experiment accelerated the initial $\mathrm{CH}_{4}$ production and the results between the assays showed a lower variability. When initial $\mathrm{P}_{\mathrm{H} 2}$ ranged from 0 to $600 \mathrm{mbars}$, a slight increase of $\mathrm{CH}_{4}$ production was observed from $23 \pm 4 \mathrm{~mL} \mathrm{CH} 4 / \mathrm{g}$ TS to $28 \pm 6.1 \mathrm{~mL} \mathrm{CH} 4 / \mathrm{g}$ TS, respectively.. This increase was due to a partial consumption of the $\mathrm{H}_{2}$ initially added. At higher initial $\mathrm{P}_{\mathrm{H} 2}$, cumulative production of $\mathrm{CH}_{4}$ decreased from $28 \pm 6.1 \mathrm{~mL}$ of $\mathrm{CH} 4 / \mathrm{g}$ TS down to $9 \pm 1.1 \mathrm{~mL} \mathrm{CH} 4 / \mathrm{g}$ TS at $\mathrm{P}_{\mathrm{H} 2}=1555$ mbars. Interestingly, at $\mathrm{P}_{\mathrm{H} 2}$ higher than 800900 mbars, a strong decrease of methanogenesis was observed.

Figure 1-b shows the overall substrate degradation expressed in gCOD per $\mathrm{g}$ of initial TS, after 13 days of experiment. The substrate degradation corresponded to the total amount of COD produced by AD degradation of wheat straw. Interestingly, substrate degradation decreased with the increase of initial $\mathrm{P}_{\mathrm{H} 2}$, from $0.09 \pm 0.01 \mathrm{~g} \mathrm{COD} / \mathrm{g}$ TS in the control samples to $0.02 \pm 0.01 \mathrm{~g} \mathrm{COD} / \mathrm{g}$ TS at a $\mathrm{P}_{\mathrm{H} 2}=1555$ mbars. Since total amount of metabolic end products such as methane and acidogenic VFAs decreased with the increasing of $\mathrm{P}_{\mathrm{H} 2}$, this result suggests that a strong inhibition of the initial steps of hydrolysis and/or acidogenesis occurred at initial $\mathrm{P}_{\mathrm{H} 2}$ higher than 742 mbars. An analysis of variance (ANOVA) showed that when $\mathrm{H}_{2}$ was introduced alone (1) the substrate degradation was not significantly different from controls at $\mathrm{P}_{\mathrm{H} 2}$ lower than 781 mbars, and (2) the substrate degradation was significantly different at 1050 mbars of $\mathrm{H}_{2}$ with a P-value $<0.0001$ (see more information in Supplementary material).

In addition, a low $\mathrm{pH}$ resulting from VFA accumulation could have a strong impact on methanogens. Here, since the medium was buffered, the $\mathrm{pH}$ remained the same between 8 and 9 all along the experiments. 
Figure 2 shows the cumulated amount of VFAs expressed in g COD / g TS at the end of the experiment according to initial $\mathrm{P}_{\mathrm{H} 2}$. VFAs accumulation increased from $20 \pm 4$ to $60 \pm 2 \mathrm{mg}$ $\mathrm{COD} / \mathrm{g}$ TS between $\mathrm{P}_{\mathrm{H} 2}$ of 600 mbars and 1000 mbars, respectively, and decreased at higher $\mathrm{P}_{\mathrm{H} 2}$. Acetate was the unique VFAs changing with initial $\mathrm{P}_{\mathrm{H} 2}$. The amount of acetate increased from $8 \pm 5 \mathrm{mg} \mathrm{COD} / \mathrm{g}$ TS in the control to $23 \pm 1 \mathrm{mg} \mathrm{COD} / \mathrm{g}$ TS at $600 \mathrm{mbars}$. The slight increase of acetate production at $\mathrm{P}_{\mathrm{H} 2}$ higher than 603 mbars was likely due to the consumption of $\mathrm{H}_{2}$ and $\mathrm{CO}_{2}$ by homoacetogens (Montero et al., 2009). A maximum amount of $50 \pm 3 \mathrm{mg}$ $\mathrm{COD} / \mathrm{g}$ TS was observed at 745 mbars, and the amount of acetate decreased at $\mathrm{P}_{\mathrm{H} 2}$ of 1350 mbars with $24 \pm 2 \mathrm{mg} \mathrm{COD} / \mathrm{g}$ TS.

In this study, no substantial VFAs accumulation that could explain methanogenesis inhibition was observed. Inhibition of methanogenesis by $\mathrm{H}_{2}$ partial pressure is well-known process in wet $\mathrm{AD}$, since acetogenesis is thermodynamically unfavorable when the $\mathrm{P}_{\mathrm{H} 2}$ is too high (1.01 $\mathrm{x} 10^{-3}$ mbars) resulting in VFA accumulation and changes in VFA distribution (Deublein and Steinhauser, 2008). According to the Henry's law, the dissolved $\mathrm{H}_{2}$ concentration at $35^{\circ} \mathrm{C}$ ranged from $1.14 \times 10^{-3} \mathrm{mg} / \mathrm{L}$ to $3.64 \times 10^{-2} \mathrm{mg} / \mathrm{L}$ at 52 mbars of $\mathrm{H}_{2}$ and 1545 mbars of $\mathrm{H}_{2}$, respectively. In $\mathrm{AD}, \mathrm{H}_{2}$ is continuously produced by fermentation from sugars and acetogenic bacteria from VFAs and ethanol. Since the latter reactions are endergonic, complete AD requires an immediate and rapid $\mathrm{H} 2$ consumption by methanogens to produce $\mathrm{CH}_{4}$ (Amani et al., 2010). In wet AD, methanogenic conversion of fermentative end-products generated by acidogenic and acetogenic bacteria can decrease when $\mathrm{H}_{2}$ accumulates with subsequent increase of VFAs. The $\mathrm{P}_{\mathrm{H} 2}$ value at which VFAs accumulate and methanogenesis is inhibited in wet $\mathrm{AD}$ is very low when compared to the present results. As an illustration, butyrate consumption by acetogens was reported as inhibited at a $\mathrm{P}_{\mathrm{H} 2}$ of 20.3 mbars, at $25^{\circ} \mathrm{C}$ and $\mathrm{pH} 7$, using glucose as substrate (Ahring and Westermann, 1988). However, acetogenesis and inhibition leads to a change in VFA distribution that was not observed in this study (Figure 2). When considering the amount of water contained in the medium, the maximal VFAs concentration was always lower than $17.7 \pm 0.5 \mathrm{~g}$ VFAs/L that was even below the inhibitory limit of methanogenesis $20 \mathrm{~g} / \mathrm{L}$. This inhibitory limit of methanogenesis, but not acidogenesis was reported in wet AD by Siegert and Banks (2005) using glucose and cellulose as substrates. Arslan et al. (2012) reported that $\mathrm{H}_{2}$ up to 2 bars has no effect on fermentative acetate production from carbohydrates, proteins and lipids rich waste. Additionally, AbbassiGuendouz et al (2012) reported that VFAs could accumulate under similar conditions at concentrations higher than $40 \mathrm{~g} / \mathrm{L}$ at high TS value. 
It was therefore concluded that high $\mathrm{P}_{\mathrm{H} 2}$ had a strong inhibitory impact on hydrolysis rather than acidogenesis.

In addition, the final partial pressure of $\mathrm{CO}_{2}$ and $\mathrm{H}_{2}$ remaining in headspace at the end of the experiment and according to initial $\mathrm{P}_{\mathrm{H} 2}$ are shown in Figure 3. The remaining $\mathrm{P}_{\mathrm{H} 2}$ was always lower than the amount of $\mathrm{H}_{2}$ introduced at start-up of the experiment, showing that added $\mathrm{H}_{2}$ was partially or totally consumed and no $\mathrm{H}_{2}$ was overproduced. At low initial $\mathrm{P}_{\mathrm{H} 2}, \mathrm{H}_{2}$ was fully consumed during the time of the experiments. $\mathrm{H}_{2}$ was likely used to produce acetate and $\mathrm{CH}_{4}$ at $\mathrm{P}_{\mathrm{H} 2}$ lower than 745 mbars. At a $\mathrm{P}_{\mathrm{H} 2}$ ranging between 745 and 1000 mbars, $\mathrm{H}_{2}$ was partially consumed to produce acetate by homoacetogenesis (Montero et al., 2009). Interestingly, $\mathrm{H}_{2}$ consumption was lower at high $\mathrm{P}_{\mathrm{H} 2}$ since $\mathrm{H}_{2}$ remained in the headspace at the end of the experiment with $26 \pm 23.1$ to $547 \pm 55.6$ mbars of $\mathrm{H}_{2} / \mathrm{g}$ TS for initial $\mathrm{P}_{\mathrm{H} 2}$ of 745 mbars and 1550 mbars, respectively. More precisely, $\mathrm{H}_{2}$ consumption was rapid during the first days of experiments and then slowed down rapidly according to the initial $\mathrm{P}_{\mathrm{H} 2}$. As an illustration, at 1418 mbars, $\mathrm{H}_{2}$ was rapidly consumed during the first 3 days, with a consumption rate of $206 \pm 112$ mbars of $\mathrm{H}_{2}$ per $\mathrm{g}$ TS and per day. $\mathrm{H}_{2}$ consumption rate was

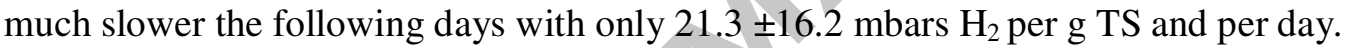
Meanwhile, the remaining $\mathrm{CO}_{2}$ in headspace was also monitored (Figure 3). The apparent remaining $\mathrm{CO}_{2}$ corresponds to a balance between $\mathrm{CO}_{2}$ production due to microbial degradation of wheat straw, and $\mathrm{CO}_{2}$ consumption to produce either $\mathrm{CH}_{4}$ by methanogens or acetate by homoacetogens, both in combination with $\mathrm{H}_{2}$. From 0 to 745 mbars, $\mathrm{CO}_{2}$ was overproduced due to microbial activity on substrate. The remaining $\mathrm{P}_{\mathrm{CO} 2}$ decreased $221 \pm 47.8$ to $67 \pm 55$ mbar of $\mathrm{CO} 2 / \mathrm{g}$ TS in the control and at a $\mathrm{P}_{\mathrm{H} 2}$ of 745 mbars, respectively. At higher $\mathrm{P}_{\mathrm{H} 2}$, no remaining $\mathrm{CO}_{2}$ was found in headspace. Since the increase of the remaining amount of $\mathrm{H}_{2}$ in headspace was correlated to the decrease of remaining $\mathrm{CO}_{2}$, it was concluded that $\mathrm{CO}_{2}$ production was the limiting factor for $\mathrm{H}_{2}$ consumption and, by consequence, $\mathrm{H}_{2}$ inhibition on the hydrolytic activity (Florin and Harris, 2008). Since both $\mathrm{CO}_{2}$ and $\mathrm{H}_{2}$ are required to produce acetate or methane, the decrease of acetate/methane production at higher $\mathrm{P}_{\mathrm{H} 2}$ may be explained by a lack of remaining $\mathrm{CO}_{2}$ in headspace.

This assumption was supported by microbial community analysis. The archaeal community of methanogens was composed of $94.6 \pm 0.6 \%$ of Methanobacteriales and only $0.5 \pm 0.6 \%$ of Methanosarcinae at 0 and 1020 mbars, as shown in Figure 4. Methanobacteriales are strict hydrogenotrophs, while members of the Methanosarcinae order are rather acetotrophs with some members exhibiting both activities. In absence of acetotrophs, acetate oxidation could 
occur in $\mathrm{AD}$, and has even been reported as main methanogenic pathway by Karakashev et al. (2006). However, acetate oxidation is thermodynamically unfavorable at high $\mathrm{P}_{\mathrm{H} 2}$ and could only occur in presence of active hydrogenotrophs. Since $\mathrm{CO} 2$ was a limiting factor, leading to subsequent $\mathrm{P}_{\mathrm{H} 2}$ accumulation by limiting the hydrogenotrophic activity, acetate was not oxidized and accumulated in the medium and lower production of methane. The concentration of 16S rRNA genes copies of Archaea or Bacteria per g of digestate measured by quantitative PCR did not change according to the initial $\mathrm{P}_{\mathrm{H} 2}$, likely because of the limited time period of 13 days. Therefore, archaeal and bacterial community structures, evaluated by CE-SSCP, showed no significant differences between the assays and it was concluded that the initial $\mathrm{P}_{\mathrm{H} 2}$ had no effect on either communities or growth of the anaerobic consortium, but rather had an impact at a cellular or physiological level (data shown in supplementary material section).

\subsection{Effect of adding $\mathrm{CO}_{2}$ with $\mathrm{H}_{2}$ on solid state $\mathrm{AD}$}

A second set of experiments was carried out to evaluate the effect of $\mathrm{CO} 2$ that is concomitantly produced with $\mathrm{H}_{2}$ during acidogenesis. Abbassi-Guendouz et al. (2012) showed methanogenesis inhibition at high solids content (>30\%) and suggested that such inhibition was due to local accumulation of $\mathrm{H}_{2}$ and $\mathrm{CO}_{2}$ leading subsequently to VFAs accumulation. To determine the exact effect of both $\mathrm{H}_{2}$ and $\mathrm{CO}_{2}$ on $\mathrm{AD}$, a mixture of both gases were initially introduced in headspace.

As control, $\mathrm{CO}_{2}$ was added alone at different initial $\mathrm{P}_{\mathrm{CO} 2}$, but no significant effect on substrate degradation was observed (see supplementary material).

Figure 5 shows the cumulative production of $\mathrm{CH}_{4}$ and VFAs as well as the remaining $\mathrm{CO}_{2}$ at the end of the experiment, according to the initial $\mathrm{P}_{\mathrm{CO} 2}$ and $\mathrm{P}_{\mathrm{H} 2}$. First, $\mathrm{CH}_{4}$ production increased when $\mathrm{CO}_{2}$ was initially added with $\mathrm{H}_{2}$ from $0.46 \pm 0.06 \mathrm{mmol} \mathrm{CH}_{4} / \mathrm{g}$ TS to $3.4 \pm$ $0.51 \mathrm{mmol} \mathrm{CH}_{4} / \mathrm{g}$ TS in the control with no $\mathrm{CO}_{2}$ and with $\mathrm{CO}_{2}$ at 1 040-1 060 mbars of $\mathrm{H}_{2}$, respectively. The remaining $\mathrm{CO}_{2}$ increased when $\mathrm{CO}_{2}$ and $\mathrm{H}_{2}$ were added together, from 0 with only $\mathrm{H}_{2}$ added to $1.25 \pm 0.3 \mathrm{mmol} \mathrm{CO} / \mathrm{g}$ TS and $1.13 \pm 0.4 \mathrm{mmol} \mathrm{CO}_{2} / \mathrm{g}$ TS at 787 mbars and 1 040-1 060 mbars of $\mathrm{H}_{2}$, respectively. Such values of $\mathrm{CO}_{2}$ indicated an overproduction of $\mathrm{CO}_{2}$ during the time of experiment. Interestingly, $\mathrm{H}_{2}$ was entirely 
consumed at the end of the experiment, when mixed with $\mathrm{CO}_{2}$ (after 2-4 days). In contrast, remaining $\mathrm{H}_{2}$ was present when $\mathrm{H}_{2}$ was added alone, from $0.4 \pm 0.4$ to $1 \pm 0.2 \mathrm{mmol} \mathrm{H}_{2} / \mathrm{g}$ TS at the end of the experiment for 781 and 1060 mbars of $\mathrm{H}_{2}$ respectively. In conclusion, microorganisms likely used both $\mathrm{CO}_{2}$ and $\mathrm{H}_{2}$ to produce $\mathrm{CH}_{4}$ by methanogenesis and/or acetate by homoacetogenesis rapidly transformed to methane. Hydrolysis inhibition did not occur since the $\mathrm{P}_{\mathrm{H} 2}$ decreased rapidly in the headspace when $\mathrm{CO}_{2}$ was added initially.

Furthermore, the total amount of VFAs was higher when $\mathrm{H}_{2}$ was added alone $(0.03 \pm 0.006 \mathrm{~g}$ VFAs/ $\mathrm{g}$ TS for both $\left.\mathrm{P}_{\mathrm{H} 2}\right)$ than for the mixture $\left(0.003 \pm 0.002 \mathrm{~g} \mathrm{VFAs} / \mathrm{g}\right.$ TS for both $\mathrm{P}_{\mathrm{H} 2} /$ $\mathrm{P}_{\mathrm{CO} 2}$ ). This result suggests that methanogenesis occurred preferentially than homoacetogenesis when both $\mathrm{CO}_{2}$ and $\mathrm{H}_{2}$ were added, which is different than in conventional wet AD (Pavlostathis and Giraldo-Gomez, 1991). This observation was confirmed by acetate concentration which was higher when only $\mathrm{H}_{2}$ was present in headspace, with $3.48 \times 10^{-4}$ mol acetate/g TS (for 781 mbars of $\mathrm{H}_{2}$ alone) than for a mixture of $\mathrm{H}_{2}$ and $\mathrm{CO}_{2}$, with $5.27 \times 10^{-5}$ mol acetate/g TS (with 787 mbars of $\mathrm{H}_{2} / 427$ mbars of $\mathrm{CO}_{2}$ ). Moreover, the overall substrate degradation increased from $7.28 \times 10^{-3} \mathrm{~g} \mathrm{COD} / \mathrm{g}$ TS at $1060 \mathrm{mbars}$ of $\mathrm{H}_{2}$ with no $\mathrm{CO}_{2}$, to $0.14 \mathrm{~g} \mathrm{COD} / \mathrm{g}$ TS at similar 1040 mbars of $\mathrm{H}_{2}$ with 324 mbars of $\mathrm{CO}_{2}$ (Table 2). The overall substrate degradation was 5 to 19 times higher when $\mathrm{CO}_{2}$ was added than with only $\mathrm{H}_{2}$. Statistically, substrate degradation was similar in control and when $\mathrm{CO}_{2}$ and $\mathrm{H}_{2}$ were added initially in headspace. In this case, hydrolysis inhibition did not occur, since $\mathrm{H}_{2}$ was consumed rapidly with $\mathrm{CO}_{2}$ by the methanogens to produce $\mathrm{CH}_{4}$, and $\mathrm{P}_{\mathrm{H} 2}$ decreased rapidly under inhibitory $\mathrm{P}_{\mathrm{H} 2}$. By adding $\mathrm{CO}_{2}$ in headspace, it was confirmed that $\mathrm{CO}_{2}$ was a limiting factor for $\mathrm{CH}_{4}$ production when $\mathrm{P}_{\mathrm{H} 2}$ was high. Hydrolysis inhibition by $\mathrm{H}_{2}$ could therefore not occur when $\mathrm{CO}_{2}$ was present in headspace, since they were both consumed to produce acetate or $\mathrm{CH}_{4}$.

All these experiments were performed with a thin layer of substrate to reduce gas transfer limitations and investigate local impact of gas partial pressure. To extend these observations to ss-AD reactor, gas transfer must also be considered. In high solids reactors, anaerobic digestion is inhibited at high TS contents (Abbassi-Guendouz et al., 2012; Motte et al., 2013). Diffusion coefficients of $\mathrm{H}_{2}$ and $\mathrm{CO}_{2}$ are also lower in ss-AD (Bollon et al., 2013). With high solids, $\mathrm{H}_{2}$ and $\mathrm{CO}_{2}$ may accumulate in the matrix and local $\mathrm{P}_{\mathrm{H} 2}$ likely increases with subsequent inhibition of hydrolysis. Diffusion of $\mathrm{CO}_{2}$ may also be slowed, and the overall inhibition observed at high solids content may result from a low amount of $\mathrm{CO}_{2}$ available to reduce hydrolysis inhibition by $\mathrm{H}_{2}$. 
Moreover, hydrolysis is already know to be a limiting factor in ss-AD (Pavlostathis and Giraldo-Gomez, 1991) and the composition of the substrate (morphological and chemical) has a strong effect on this step (Motte et al., 2014; Triolo et al., 2011). The actual mechanisms of hydrolysis are not well understood, but many models are including low hydrolysis rates (Vavilin et al., 2008). In ADM1 model, two mechanisms for the extracellular enzymes are proposed: (1) the microorganisms secrete enzymes into the liquid phase of the digestate and the enzymes have an effect directly on the substrate or (2) the microorganisms attach themselves on the substrate and produce enzymes (Batstone et al., 2002). As shown for the first time in our study, $\mathrm{H}_{2}$ produced during fast hydrolysis of readily accessible carbohydrates, could act as a strong inhibitor of the hydrolytic activity of microorganisms, either on production or secretion of extracellular enzymes, or on attachment and physiological cellular activity.

In previous study, modeling of ss-AD showed that a structuration of the microorganisms could occur, dependent of VFAs concentration and $\mathrm{pH}$ (Martin, 2001). Since $\mathrm{H}_{2}$ and $\mathrm{CO}_{2}$ are produced by acidogenic and acetogenic bacteria, dissolved gases may accumulate transitory in high solids reactors, with low availability to methanogens growing at a higher $\mathrm{pH}$ of 7-8. Thus, at high solids content, local accumulation of gases may result in inhibition of the overall process of methanogenesis as suggested in Abbassi-Guendouz et al. (2012). The authors reported a strong inhibition of $\mathrm{CH}_{4}$ production at TS content higher than $30 \%$, with an increase of VFAs concentration up to $40 \mathrm{~g} / \mathrm{L}$ and a decrease of $\mathrm{pH}$ from 7 to 6 . By modeling the process, it was shown that gas transfer was probably a limiting factor for the production of $\mathrm{CH}_{4}$ since $\mathrm{H}_{2}$ and $\mathrm{CO}_{2}$ may be used locally to produce acetate by homoacetogenic bacteria and since acidogens and acetogens are able to grow in same conditions rather unfavorable to methanogens, i.e. at low pH (Diekert and Wohlfarth, 1994).

\section{Conclusion}

This study provides new insight about an inhibitory effect of $\mathrm{H}_{2}$ on organic matter hydrolysis in ss-AD, using wheat straw as substrate. By adding $\mathrm{CO}_{2}$, hydrolysis inhibition was suppressed, indicating that $\mathrm{CO}_{2}$ was the limiting factor to avoid $\mathrm{H}_{2}$ inhibition in ss-AD. These results were obtained with a thin layer of substrate to avoid the effect of the gas transfer. Even though the strong inhibitory effect of $\mathrm{H}_{2}$ was only observed at a local scale, inhibition of $\mathrm{AD}$ at high solids content may result from similar mechanisms when low gas diffusion rates create high local $\mathrm{H}_{2}$ accumulation. 


\section{Acknowledgements}

This work was supported by the French Environment and Energy Management Agency (ADEME) and the French Institute for Agricultural and Food Research (INRA).

\section{References}

1. Abbassi-Guendouz, A., Brockmann, D., Trably, E., Dumas, C., Delgenès, J.-P., Steyer, J.-P., Escudié, R., 2012. Total solids content drives high solid anaerobic digestion via mass transfer limitation. Bioresour. Technol. 111, 55-61.

2. Ahring, B.K., Westermann, P., 1988. Product inhibition of butyrate metabolism by acetate and hydrogen in a thermophilic coculture. Appl. Environ. Microbiol. 54, 23937.

3. Amani, T., Nosrati, M., Sreekrishnan, T., 2010. Anaerobic digestion from the viewpoint of microbiological, chemical, and operational aspects - a review. Environ. Rev. 18, 255-278.

4. Arslan, D., Steinbusch, K.J.J., Diels, L., De Wever, H., Buisman, C.J.N., Hamelers, H.V.M., 2012. Effect of hydrogen and carbon dioxide on carboxylic acids patterns in mixed culture fermentation. Bioresour. Technol. 118, 227-34.

5. Baere, L. De, Mattheeuws, B., Velghe, F., 2010. State of the art of anaerobic digestion in Europe. 12th World Congr. Anaerob. Dig. 32.

6. Batstone, D.J., Keller, J., Angelidaki, I., Kalyuzhnyi, S. V, Pavlostathis, S.G., Rozzi, A., Sanders, W.T.M., Siegrist, H., Vavilin, V. a, 2002. The IWA Anaerobic Digestion Model No 1 (ADM1). Water Sci. Technol. 45, 65-73.

7. Bollon, J., Benbelkacem, H., Gourdon, R., Buffiere, P., 2013. Measurement of diffusion coefficients in dry anaerobic digestion media. Chem. Eng. Sci. 89, 115-119.

8. Braun, F., Hamelin, J., Gévaudan, G., Patureau, D., 2011. Development and application of an enzymatic and cell flotation treatment for the recovery of viable microbial cells from environmental matrices such as anaerobic sludge. Appl. Environ. Microbiol. 77, 8487-93.

9. Brown, D., Shi, J., Li, Y., 2012. Comparison of Solid-State to Liquid Anaerobic Digestion of Lignocellulosic Feedstocks for Biogas Production. Bioresour. Technol. 124, 379-86.

10. Bru, K., Blazy, V., Joulian, C., Trably, E., Latrille, E., Quéméneur, M., Dictor, M.-C., 2012. Innovative $\mathrm{CO} 2$ pretreatment for enhancing biohydrogen production from the organic fraction of municipal solid waste (OFMSW). Int. J. Hydrogen Energy 37, 14062-14071.

11. Deublein, D., Steinhauser, A., 2008. Biogas from Waste and Renewable Resources : An Introduction. WILEY-VCH Verlag GmbH $\backslash \&$ Co. KGaA, Weinheim.

12. Diekert, G., Wohlfarth, G., 1994. Metabolism of homoacetogens. Antonie Van Leeuwenhoek 66, 209-221.

13. Ding, H.-B., Tan, G.-Y.A., Wang, J.-Y., 2010. Caproate formation in mixed-culture fermentative hydrogen production., Bioresource technology. Elsevier Ltd.

14. Fernández, J., Pérez, M., Romero, L.I., 2008. Effect of substrate concentration on dry mesophilic anaerobic digestion of organic fraction of municipal solid waste (OFMSW). Bioresour. Technol. 99, 6075-80. 
15. Florin, N.H., Harris, A.T., 2008. Enhanced hydrogen production from biomass with in situ carbon dioxide capture using calcium oxide sorbents. Chem. Eng. Sci. 63, 287316.

16. Fritsch, M., Hartmeier, W., Chang, J.S., 2008. Enhancing hydrogen production of Clostridium butyricum using a column reactor with square-structured ceramic fittings. Int. J. Hydrogen Energy 33, 6549-6557.

17. García-Bernet, D., Buffière, P., Latrille, E., Steyer, J.-P., Escudié, R., 2011. Water distribution in biowastes and digestates of dry anaerobic digestion technology. Chem. Eng. J. 172, 924-928.

18. Hallenbeck, P.C., 2005. Fundamentals of the fermentative production of hydrogen. Water Sci. Technol. 52, 21-9.

19. Karakashev, D., Batstone, D.J., Trably, E., Angelidaki, I., 2006. Acetate oxidation is the dominant methanogenic pathway from acetate in the absence of Methanosaetaceae. Appl. Environ. Microbiol. 72, 5138-41.

20. Liew, L.N., Shi, J., Li, Y., 2012. Methane production from solid-state anaerobic digestion of lignocellulosic biomass. Biomass and Bioenergy 1-8.

21. Martin, D.J., 2001. The site of reaction in solid-state digestion: a new hypothesis. Trans IChemE 79, part B.

22. Montero, B., Garcia-Morales, J.L., Sales, D., Solera, R., 2008. Evolution of microorganisms in thermophilic-dry anaerobic digestion. Bioresour. Technol. 99, 3233-43.

23. Montero, B., Garcia-Morales, J.L., Sales, D., Solera, R., 2009. Analysis of methanogenic activity in a thermophilic-dry anaerobic reactor: use of fluorescent in situ hybridization. Waste Manag. 29, 1144-51.

24. Motte, J.-C., Escudié, R., Beaufils, N., Steyer, J.-P., Bernet, N., Delgenès, J.-P., Dumas, C., 2014. Morphological structures of wheat straw strongly impacts its anaerobic digestion. Ind. Crops Prod. 52, 695-701.

25. Motte, J.-C., Trably, E., Escudié, R., Hamelin, J., Steyer, J.-P., Bernet, N., Delgenes, J.-P., Dumas, C., 2013. Total solids content: a key parameter of metabolic pathways in dry anaerobic digestion. Biotechnol. Biofuels 6, 164.

26. Pavlostathis, S.G., Giraldo-Gomez, G., 1991. Kinetics of anaerobic treatment. Water Sci. Technol. 24, 35-59.

27. Pommier, S., Chenu, D., 2007. A logistic model for the prediction of the influence of water on the solid waste methanization in landfills. Biotechnol. Bioeng. 97, 473-482.

28. Schloss, P.D., Westcott, S.L., Ryabin, T., Hall, J.R., Hartmann, M., Hollister, E.B., Lesniewski, R. a., Oakley, B.B., Parks, D.H., Robinson, C.J., Sahl, J.W., Stres, B., Thallinger, G.G., Van Horn, D.J., Weber, C.F., 2009. Introducing mothur: Opensource, platform-independent, community-supported software for describing and comparing microbial communities. Appl. Environ. Microbiol. 75, 7537-7541.

29. Siegert, I., Banks, C., 2005. The effect of volatile fatty acid additions on the anaerobic digestion of cellulose and glucose in batch reactors. Process Biochem. 40, 3412-3418.

30. Staley, B.F., de Los Reyes, F.L., Barlaz, M. a, 2011. Effect of spatial differences in microbial activity, $\mathrm{pH}$, and substrate levels on methanogenesis initiation in refuse. Appl. Environ. Microbiol. 77, 2381-2391.

31. Triolo, J.M., Sommer, S.G., Møller, H.B., Weisbjerg, M.R., Jiang, X.Y., 2011. A new algorithm to characterize biodegradability of biomass during anaerobic digestion: influence of lignin concentration on methane production potential. Bioresour. Technol. $102,9395-402$.

32. Vassilev, S. V., Baxter, D., Andersen, L.K., Vassileva, C.G., Morgan, T.J., 2012. An overview of the organic and inorganic phase composition of biomass. Fuel 94, 1-33. 
33. Vavilin, V. a, Fernandez, B., Palatsi, J., Flotats, X., 2008. Hydrolysis kinetics in anaerobic degradation of particulate organic material: an overview. Waste Manag. 28, 939-51.

34. Weiland, P., 2010. Biogas production: current state and perspectives. Appl. Microbiol. Biotechnol. 85, 849-60.

35. Wéry, N., Bru-Adan, V., Minervini, C., Delgénes, J.-P., Garrelly, L., Godon, J.-J., 2008. Dynamics of Legionella spp. and bacterial populations during the proliferation of L. pneumophila in a cooling tower facility. Appl. Environ. Microbiol. 74, 3030-7.

\section{Figures Captions}

Figure 1: Anaerobic digestion performances on wheat straw at 25\% of TS according to the initial $\mathrm{H}_{2}$ partial pressure in headspace (in mbars), expressed in terms of (1.A) cumulative $\mathrm{CH}_{4}$ production (in $\mathrm{mL} \mathrm{CH}_{4} / \mathrm{g} \mathrm{TS}_{\text {initial }}$ ), or (1.B) substrate degradation (in $\mathrm{g} \mathrm{COD} \mathrm{/g} \mathrm{TS}$ initial)

Figure 2 : Volatile Fatty Acids accumulation at the end of the experiment (in $\mathrm{g}$ COD / $\mathrm{g}$ $\mathrm{TS}_{\text {initial }}$ ) according to initial partial pressure of $\mathrm{H}_{2}$, at $25 \% \mathrm{TS}, 35^{\circ} \mathrm{C}$ and $\mathrm{pH} 8$.

Figure 3 : Final partial pressure of $\mathrm{CO}_{2}\left(\mathrm{P}_{\mathrm{CO} 2}\right)$ and $\mathrm{H}_{2}\left(\mathrm{P}_{\mathrm{H} 2}\right)$ according to the initial partial pressure of $\mathrm{H}_{2}$ (in mbars), at $25 \% \mathrm{TS}, 35^{\circ} \mathrm{C}$ and $\mathrm{pH}$ 8. Final $\mathrm{P}_{\mathrm{CO} 2}$ and $\mathrm{P}_{\mathrm{H} 2}$ in the headspace are represented with white circles and dark circles, respectively.

Figure 4: Microbial community composition at Order level of the archaeal community, in the inoculum (Initial), in the control (0mbars) and at 1020 mbars of $\mathrm{H}_{2}$, with $25 \%$ of totals solids, $35^{\circ} \mathrm{C}$ and $\mathrm{pH} 8$.

Figure 5 : Final product accumulation (gas and metabolites) (in mol per g of initial TS) according to the initial partial pressure of $\mathrm{H}_{2}$ (on the first line) and $\mathrm{CO}_{2}$ (on the second line) (in mbars) at $25 \% \mathrm{TS}, 35^{\circ} \mathrm{C}$ and $\mathrm{pH} 8$.

\section{Tables Captions}

Table 1 : Gas partial pressure investigated in different runs.

Table 2 : Final substrate degradation (in g COD per $\mathrm{g}$ of initial TS) according to the initial partial pressure of $\mathrm{H}_{2}$ and $\mathrm{CO}_{2}$ (in mbars). Similarity was determined by ANOVA (analysis of variance) test between the control ( 0 mbars of $\mathrm{CO}_{2}$ and 0 mbars of $\mathrm{H}_{2}$ ) and when $\mathrm{H}_{2}$ and/or $\mathrm{CO}_{2}$ were added. Non-significant $\mathrm{P}$-value are $>0.05$ (Similar) and significant $\mathrm{P}$-values are $<0.05 ;<0.01$ and $<0.001$ (Different). 

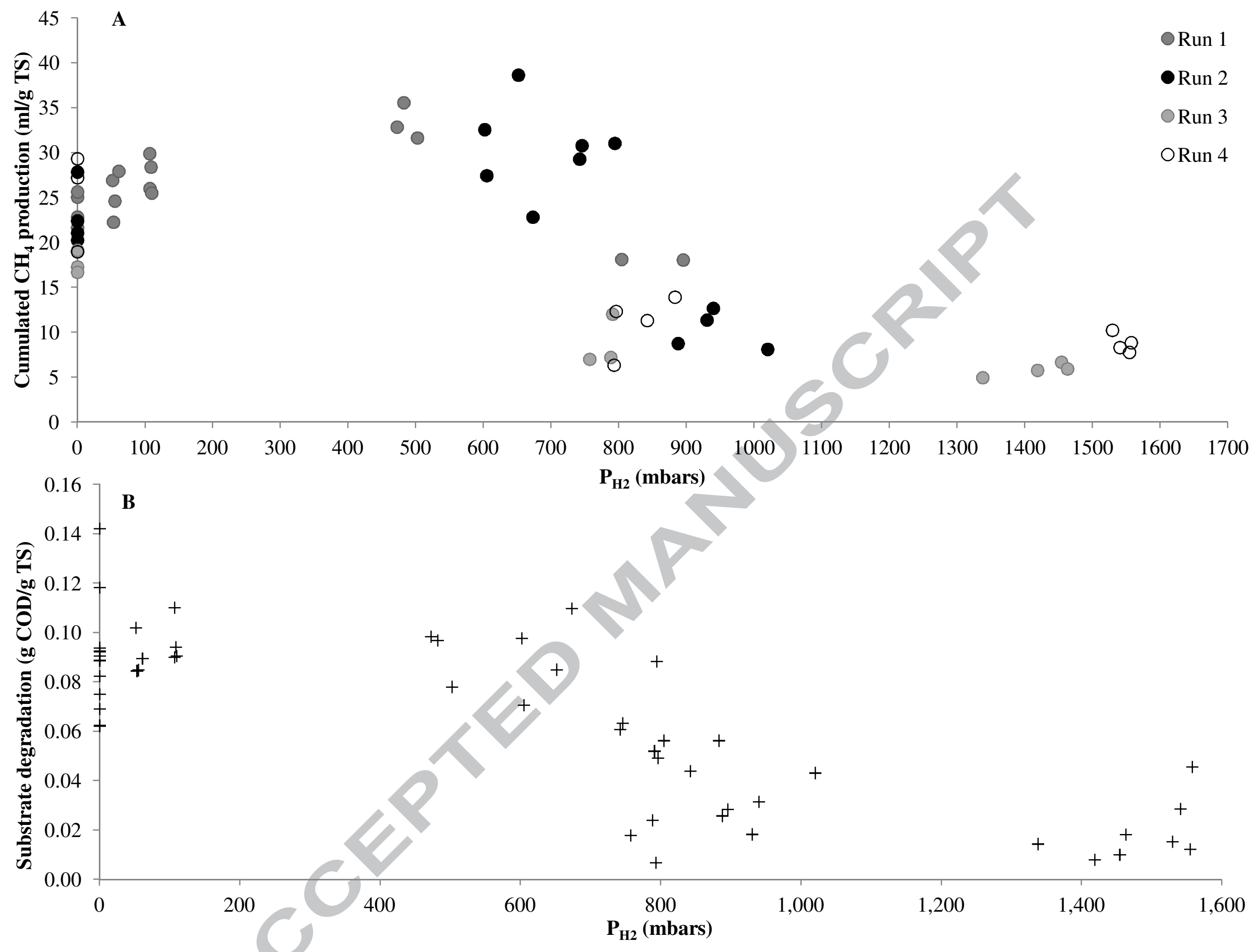


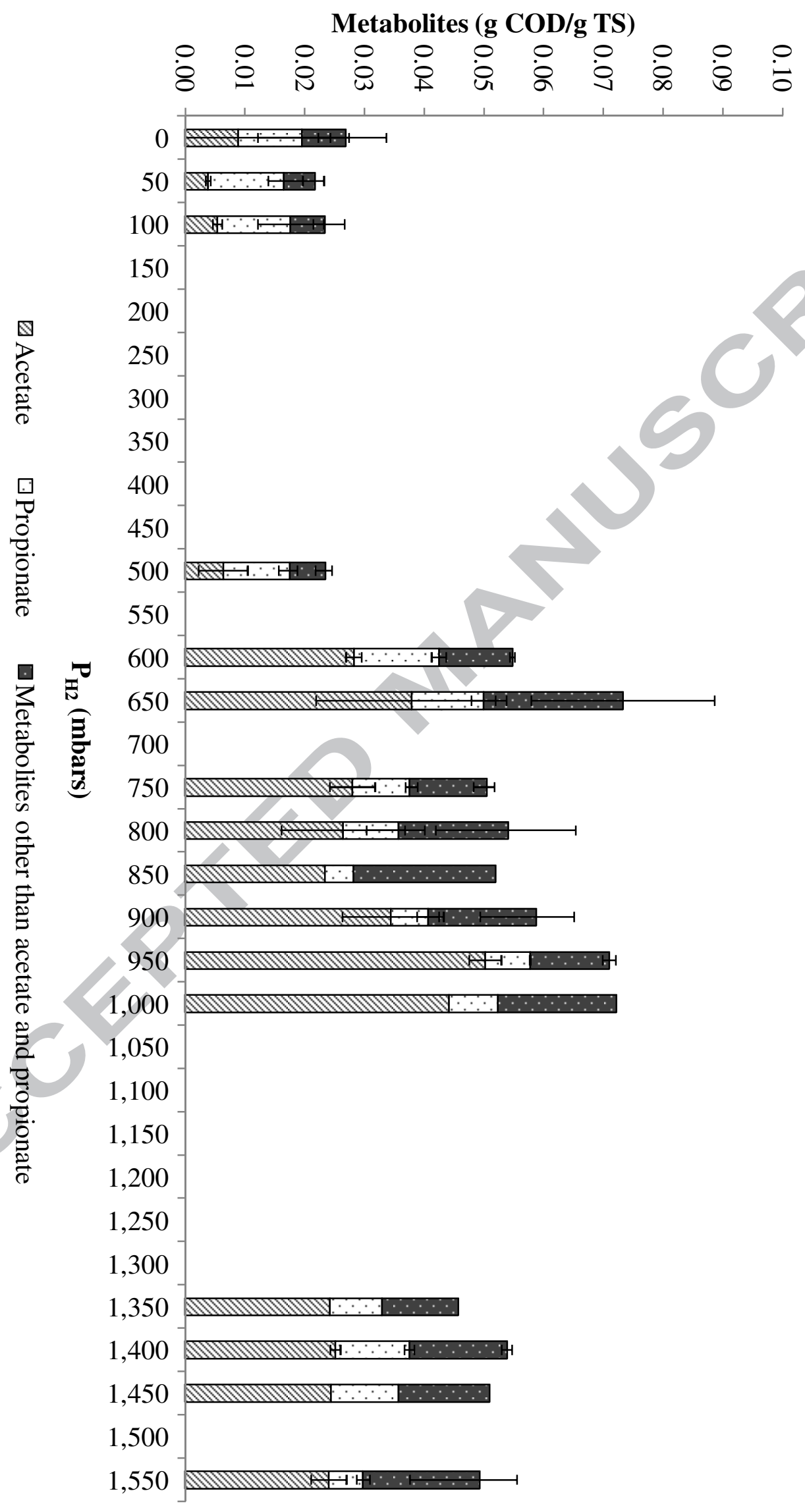




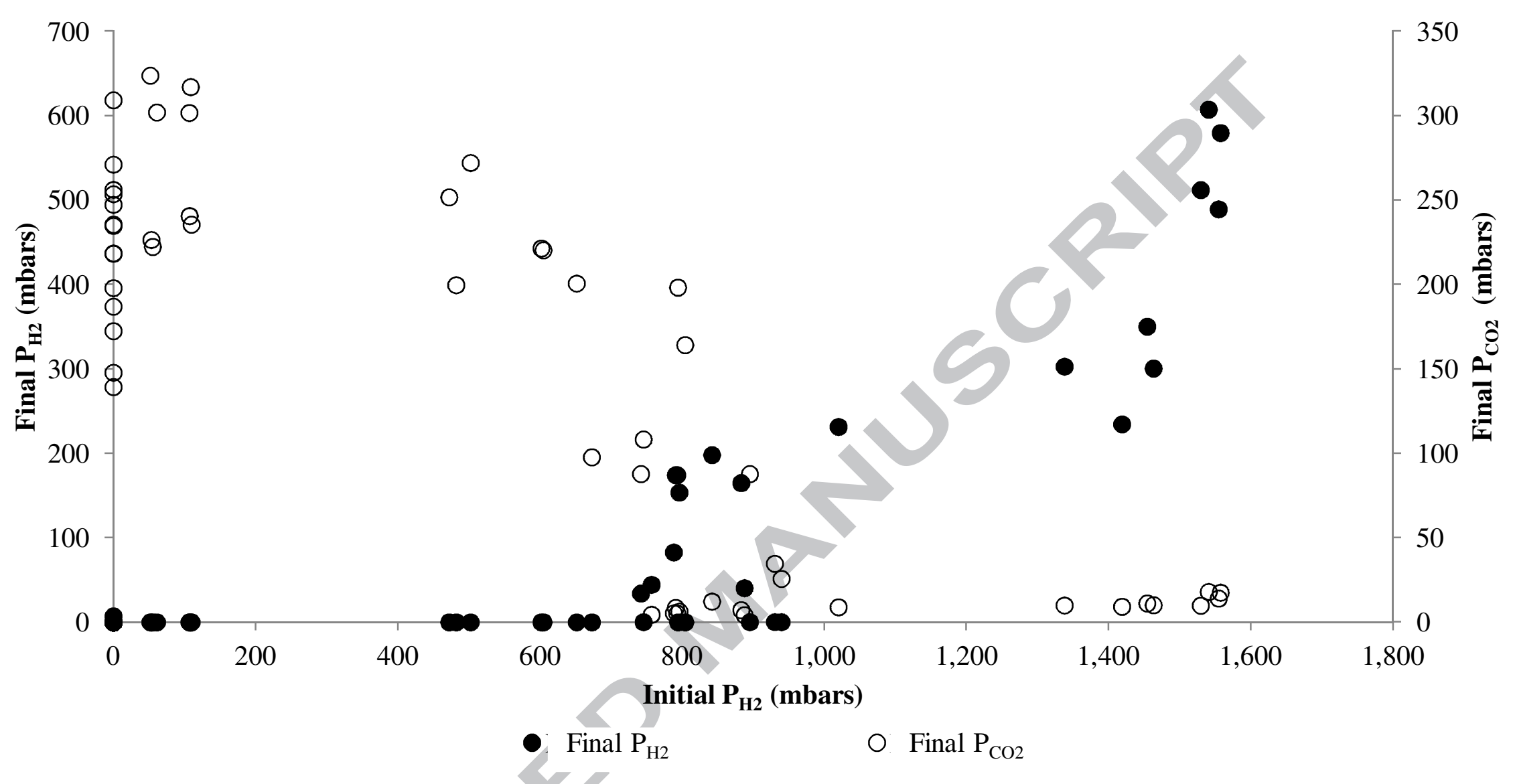




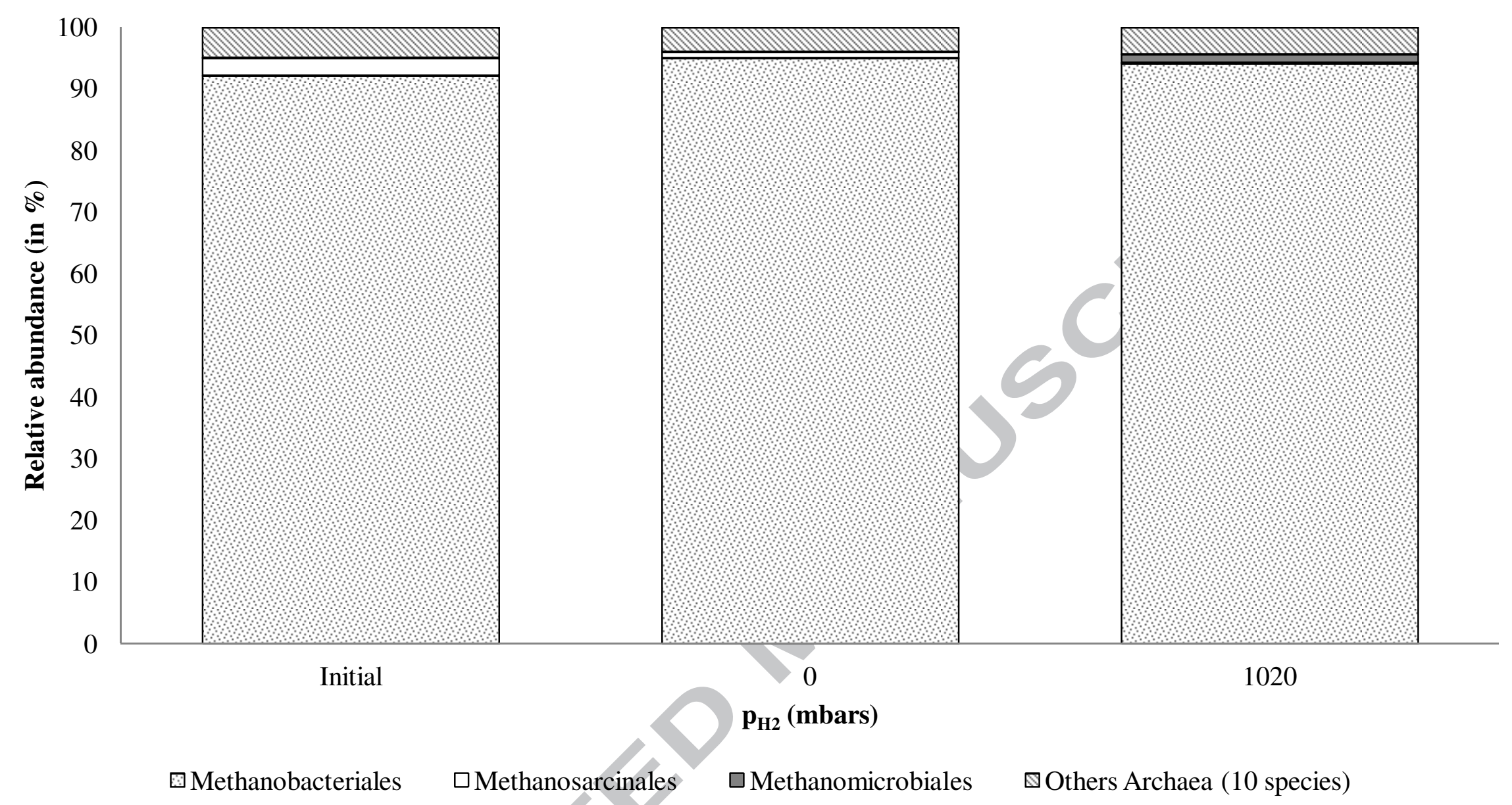




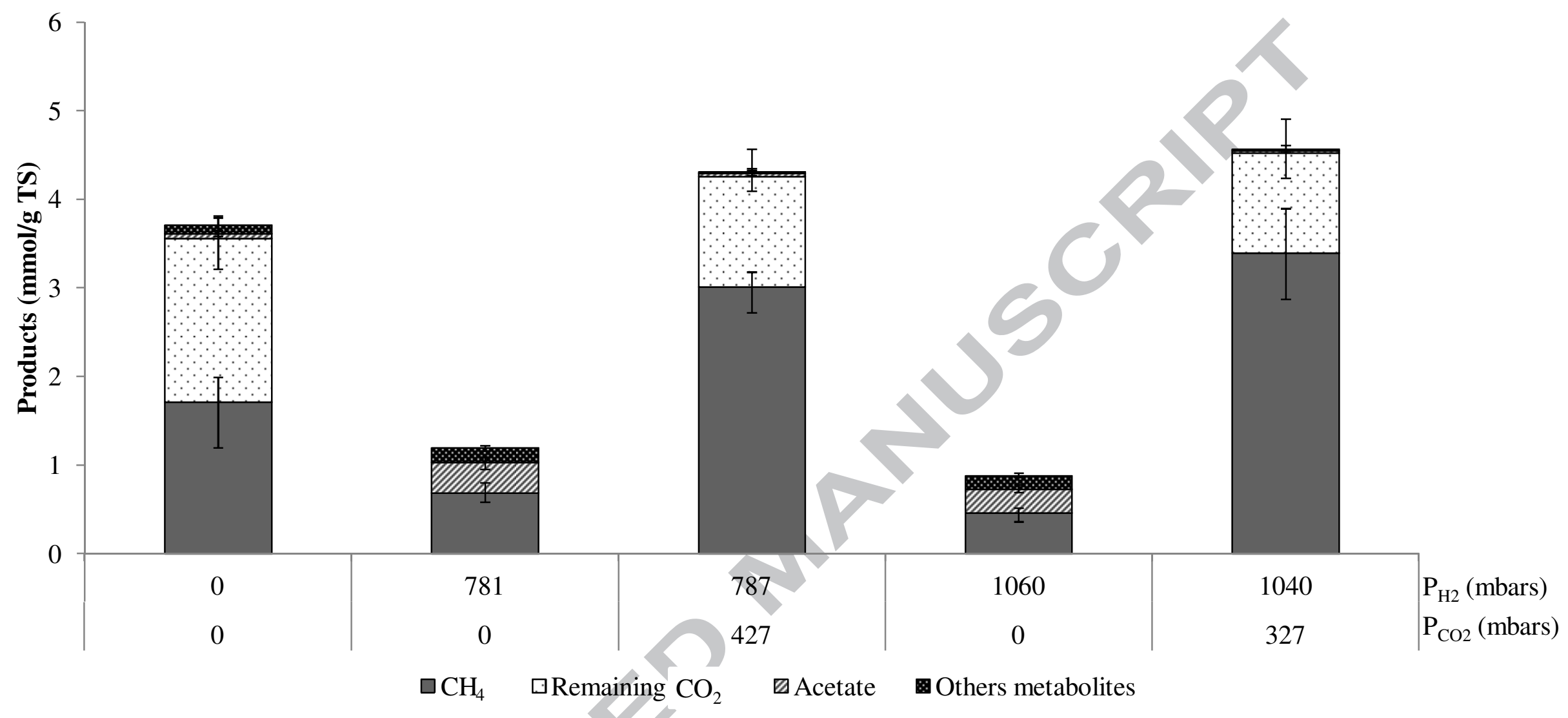




\begin{tabular}{lll}
\hline Runs & Partial pressure of $\mathbf{H}_{2}$ (mbars) & Partial pressure of $\mathbf{C O}_{\mathbf{2}}$ (mbars) \\
\hline $\mathbf{1}$ & $0,55,105,485$ and 895 & 0 \\
$\mathbf{2}$ & $0,650,750,932$ and 1020 & 0 \\
$\mathbf{3}$ & 0,778 and 1418 & 0 \\
$\mathbf{4}$ & 0,828 and 1545 & 0 \\
$\mathbf{5}$ & 0,780 and 1060 & 0,327 and 427 \\
\hline
\end{tabular}




\begin{tabular}{lll}
\hline Initial partial pressure of $\mathbf{H}_{2}$ & $\begin{array}{l}\text { Initial partial pressure of } \\
\mathbf{C O}_{2}\end{array}$ & Substrate degradation \\
(mbars) & (mbars) & \\
\hline $\mathbf{0}$ & 0 & $0.11 \pm 0.018$ \\
$\mathbf{7 8 1}$ & 0 & $0.03 \pm 0.01$ (Different) \\
$\mathbf{7 8 7}$ & 427 & $0.13 \pm 0.01$ (Similar) \\
$\mathbf{1 0 6 0}$ & 0 & $0.01 \pm 0.01$ (Different) \\
$\mathbf{1 0 4 0}$ & 327 & $0.14 \pm 0.03$ (Similar) \\
\hline
\end{tabular}




\section{Highlights}

- $\mathrm{H}_{2}$ partial pressure inhibits specifically hydrolysis in mesophilic SS-AD.

- $\mathrm{CO}_{2}$ is a limiting factor for $\mathrm{CH}_{4}$ production in $\mathrm{SS}-\mathrm{AD}$ through $\mathrm{H}_{2}$ consumption.

- Microbial community is not impacted by $\mathrm{H}_{2}$ inhibition 